Editorial

\title{
Researching the Complex, Hybrid, and Liminal Nature of Contemporary Promotional Cultures
}

\author{
Ian Somerville ${ }^{1, *}$ and Lee Edwards ${ }^{2}$ \\ ${ }^{1}$ School of Media, Communication and Sociology, University of Leicester, UK; E-Mail: ijas1@le.ac.uk \\ 2 Department of Media and Communications, London School of Economics and Political Science, UK; \\ E-Mail: I.edwards2@lse.ac.uk \\ * Corresponding author
}

Submitted: 20 May 2021 | Published: 5 August 2021

\begin{abstract}
This thematic issue invited submissions that address the challenges of researching the complex, hybrid, and liminal nature of promotional cultures and the published articles include studies which reflect on the structures, technologies, agents, representations, effects, and ethics of promotion. They are united by a central question: What strategies do we use to explore and attempt to understand the assemblages of technologies, texts, networks, and actors in contemporary promotion? We hope the collection of perspectives gathered here help to address the challenges of researching the digital, excavating promotional ideologies, confronting professions, engaging audiences through academic work, and confronting the risks and realities of research that can equally promote change or speak into a vacuum.
\end{abstract}

\section{Keywords}

complexity; hybridity; liminality; promotional cultures; promotional ethics

Issue

This editorial is part of the issue "Complexity, Hybridity, Liminality: Challenges of Researching Contemporary Promotional Cultures" edited by lan Somerville (University of Leicester, UK) and Lee Edwards (London School of Economics and Political Science, UK).

(C) 2021 by the authors; licensee Cogitatio (Lisbon, Portugal). This editorial is licensed under a Creative Commons Attribution 4.0 International License (CC BY).

We live in a time characterised by uncertainty, hybridity, and complexity, when the powerful dualisms that characterised the post-Enlightenment era (e.g., nature/society, human/machine, male/female) are being problematised in a fundamental way. This thematic issue of Media and Communication explores how we research the promotional cultures that have become central to the liminal times in which we live. The majority of the contributions originated as papers presented at a European Communication Research and Education Association (ECREA) conference in February 2020, co-sponsored by ECREA's Organisational and Strategic Communication Section, the Department of Media and Communications, LSE, and the School of Media, Communication and Sociology, University of Leicester. They are united by a central question: What strategies do we use to explore and attempt to understand the assemblages of technologies, texts, networks, and actors in contemporary promotion?

The moniker 'promotional culture' is now wellestablished as a way of describing the ubiquitous presence of promotional work-whether public relations, branding, advertising, or other forms-in all aspects of our lives (Davis, 2013). It is enacted by organisations working in all sectors, from politics to the arts, in non-profit and commercial environments, while individuals also adopt promotional techniques in the ways they present themselves and their lives to others (Edwards, 2018). However, the singularity of the term 'culture' belies the fluid and complex worlds on which promotion is built, with which it engages, and that it perpetuates. Organisations that use promotional tools in their 
strategic communication can be implicated in the worst excesses of persuasion and propaganda, but can also contribute to positive social change (Demetrious, 2013; Somerville \& Aroussi, 2013). Communication campaigns track, survey, and instrumentalise our lives through their endless appetite for data, yet ensure organisations can deliver convenience and interest precisely because they know us so well (Turow, 2017). Mainstream public relations and advertising tactics are used to sell us cars, face creams and holidays, and are deployed to greenwash environmental damage, whitewash corporate corruption, woke-wash social causes, and frame political opportunism as strategic thinking (Aronczyk \& Espinoza, 2021; Lounasmeri, 2018; Sobande, 2019). Promotional culture cannot be pinned down to one form, process, or purpose, so how do we account for its complex modes of production and deployment in our research questions, methods, and sites?

To talk about promotional culture is to acknowledge the deep embeddedness of promotion in quotidian life and the importance of its circulatory dynamics (Aronczyk, 2013). Just as Williams (1981) argued that culture is a 'whole way of life' rather than an elite set of activities, when individuals use promotional tools and tactics on their own terms, those tools are transformed from being a mechanism of elite power and repurposed to serve our own agency. Agentic power circulates through promotional work, via digital and analogue channels, and with unpredictable outcomes (Collister, 2016; Hutchins \& Tindall, 2016). In this sense, promotional culture is a continually emergent manifestation of the struggle between agency and structure, a hybrid form of power where the outcome is never certain. Can research adequately address the tensions and power struggles that underpin all promotional work, including inequalities within and between nations and regions in the Global North and the Global South? To what extent do we incorporate a wide range of sites, voices and articulations of its effects, and where are the gaps in our current practice?

The articles in this thematic issue address a range of topics, from popular culture, to the tensions between agency and structure, to methodological and conceptual issues. Popular culture is the focus for Kolotouchkina et al. (2021), for Wu (2021) and for Edlom and Karlsson (2021), who all engage with popular culture case studies to explore the effects of promotional culture on the ways in which we see ourselves and others. In "Disability Narratives in Sports Communication: Tokyo 2020 Paralympic Games' Best Practices and Implications," Kolotouchkina et al. (2021) analyse the Paralympic Games as a critical moment for communication that has the potential to enhance global awareness and understanding about disability. They argue that the increasing visibility of this kind of global spectacle and the efforts of public authorities to raise the standards of accessibility in their host cities, evidence a shift to new, urban barrier-free experiences and discourses concerning disability. Their exploratory case study assesses dis- ability representation and narratives within the context of the 2020 Tokyo Paralympic Games and their analysis of innovative communication strategies fostering the visibility of disability reveals a series of effective practices implemented in Japan.

Yuqing Wu's (2021) "Can Pop Culture Allay Resentment? Japan's Influence in China Today" notes that in China, despite the traumatic collective memory relating to the militaristic Japan during World War II, an increasing number of Chinese young adults have developed an obsession with Japanese culture largely due to the anime, movies, pop music, and other popular culture that Japan exports. Her interview-based article examines how the co-existence of contemporary pop culture and historical war memory related to Japan allows Chinese young adults to reconcile their contradictory sentiments toward the Japanese government, Japanese people, and Japanese culture. She concludes that the success of Japanese pop culture in China demonstrates how the allegedly apolitical, virtual sphere of entertainment has helped build Japan's soft power through shaping a cool image of Japan in Asia and worldwide.

In "Keep the Fire Burning: Exploring the Hierarchies of Music Fandom and the Motivations of Superfans," Edlom and Karlsson (2021) start from the position that the Internet has changed how music fans come together and how the music industry connects to and communicates with these fans. Extending existing research on fan hierarchies in digital promotional culture, they use a qualitative and digital ethnographic approach in both online and offline contexts to analyse the case of the Swedish music artist Robyn and her Facebook fan community Konichiwa Bitches. Their analysis of fan hierarchies focuses on the incentives for engagement by the superfans and executive fans at the top of the hierarchy. They conclude that these 'high-level fans' function as a key connecting point between the brand management and the fans more widely.

Camille Reyes and Emily West both focus on the tensions between agency and structure that emerge in the context of promotional work. Reyes' (2021) "Spinning at the Border: Employee Activism in 'Big PR,'” develops and extends Coombs and Holladay's social issues management model to provide new perspectives on activism and public relations. The study fills a gap in the literature on internal activism by analysing the case of The Ogilvy Group and their employees, many of whom pushed for the agency to resign its work for U.S. Customs and Border Protection during President Trump's period in office. Reyes' study uses a textual analysis of a leaked transcript which documents a meeting between Ogilvy management and internal activist employees to examine how the communicative tasks of definition, legitimation, and awareness are explored in a way that complicates identity and power.

In West's (2021) "Review Pollution: Pedagogy for a Post-Truth Society" she notes that today consumer reviews on platforms like Amazon are summarised into 
star ratings, used to weight search results, and consulted by consumers to guide purchase decisions. She suggests such reviews are emblematic of the interactive digital environment that has purportedly transferred power from marketers to 'regular people,' and yet at the same time they represent the infiltration of promotional concerns into online information. Thus, consumers' ratings and reviews do promotional work for brands and the platforms that host reviews and any gains in power by consumers are quickly met with new strategies of control by companies who depend on reviews for reputational capital. West's study focuses on ecommerce giant Amazon to explore the complexities of online reviews and examines how individual efforts to provide product feedback and help others make choices become transformed into an information commodity and promotional vehicle.

Olaf Hoffjann (2021), in "The Innovation Function of Hybridization in Public Relations," notes that marketing and public relations literature focused on strategic communication contains many examples of hybrid structures, and that this raises the key question of what problems these hybrid structures solve. Public relations is itself the result of a hybridization process, he argues, and exemplifies hybridization as a process by which a social system adopts program structures of another system, in processes of strategic innovation. He concludes that in order to be able to continue to influence decisions in the interest of those it serves, public relations unscrupulously adopts structures of journalism, advertising, and entertainment, in order to strategically address challenges relating to the trustworthiness, attention, and relevance of its communication objects.

Our final article tackles head on the complex methodological demands of promotional research. Bengtsson and Edlom's (2021) "Mapping Transmedia Marketing in the Music Industry: A Methodology" begins with the observation that over the last decade, the music industry has adapted its promotional strategy to take advantage of the fluid, contemporary, platform-based transmedia landscape, and the multiplicity of promotional activities creates substantial methodological challenges. Guided by the Association of Internet Researchers' (AolR) ethical guidelines, they explore two data collection strategiesreversed engineering and live capturing-and apply two analytical approaches-visual mapping and time-based layering. Reflecting on the findings from these case studies, they argue for three methodological principles to be applied to such sites. First, for the importance of manual capturing and coding in data collection, especially when working around data access limitations imposed by platforms. Second, to use reversed engineering and live capturing as methods of capturing fragmented data in contemporary promotional campaigns. Finally, they suggest visual mapping and time-based layering of data to enable researchers to oscillate between qualitative and quantitative data. They suggest that researchers should be ready to share research experiences and resources regarding how to transcend platform limitations and be willing to question any lack of transparency while respecting ethical norms and guidelines.

This thematic issue invited submissions that address the challenges of researching the complex, hybrid, and liminal nature of promotion in a range of ways and the published articles include studies that reflect on the structures, technologies, agents, representations, effects, and ethics of promotion. We hope the collection of perspectives gathered here help to address the challenges of researching the digital, excavating promotional ideologies, confronting professions, engaging audiences through academic work, and confronting the risks and realities of research that can equally promote change or speak into a vacuum.

\section{Conflict of Interests}

The authors declare no conflict of interests.

\section{References}

Aronczyk, M. (2013). The transnational promotional class and the circulation of value(s). In M. McAllister \& E. West (Eds.), The Routledge companion to advertising and promotional culture (pp. 159-173). Routledge.

Aronczyk, M., \& Espinoza, M. (2021). A strategic nature: Public relations and the politics of American environmentalism. Oxford University Press.

Bengtsson, L. R., \& Edlom, J. (2021). Mapping transmedia marketing in the music industry: A methodology. Media and Communication, 9(3), 164-174.

Collister, S. (2016). Algorithmic public relations: Materiality, technology and power in a post-hegemonic world. In J. L'Etang, D. McKie, N. Snow, \& J. Xifra (Eds.), The Routledge handbook of public relations (pp. 360-371). Routledge.

Davis, A. (2013). Promotional cultures: The rise and spread of advertising, public relations, marketing and branding. Polity Press.

Demetrious, K. (2013). Public relations, activism and social change: Speaking up. Routledge.

Edlom, J., \& Karlsson, J. (2021). Keep the fire burning: Exploring the hierarchies of music fandom and the motivations of superfans. Media and Communication, 9(3), 123-132.

Edwards, L. (2018). Understanding public relations: Theory, culture and society. Sage.

Hoffjann, O. (2021). The innovation function of hybridization in public relations. Media and Communication, 9(3), 155-163.

Hutchins, A., \& Tindall, N. (2016). New media, new media relations: Building relations with bloggers, citizen journalists and engaged publics. In A. Hutchins \& N. Tindall (Eds.), Public relations and participatory culture (pp. 103-115). Routledge.

Kolotouchkina, O., Llorente-Barroso, C., García-Guardia, M. L., \& Pavón, J. (2021). Disability narratives 
in sports communication: Tokyo 2020 Paralympic games' best practices and implications. Media and Communication, 9(3), 101-111.

Lounasmeri, L. (2018). The emergence of PR consultants as part of the Finnish political communication elite. Journal of Contemporary European Studies, 26(4), 377-391. https://doi.org/10.1080/14782804. 2018.1436530

Reyes, C. (2021). Spinning at the border: Employee activism in 'big PR'. Media and Communication, 9(3), 133-143.

Sobande, F. (2019). Woke-washing: 'Intersectional' femvertising and branding 'woke' bravery. European Journal of Marketing, 54(11), 2723-2745. https://doi.org/10.1108/EJM-02-2019-0134

Somerville, I., \& Aroussi, S. (2013). Campaigning for 'women, peace and security': Transnational advocacy networks at the United Nations Security Council. In C. Daymon \& K. Demetrious (Eds.), Gender and public relations: Critical perspectives on voice, image and identity (pp. 156-176). Routledge.

Turow, J. (2017). The aisles have eyes: How retailers track your shopping, strip your privacy, and define your power. Yale University Press.

West, E. (2021). Review pollution: Pedagogy for a post-truth society. Media and Communication, 9(3), 144-154.

Williams, R. (1981). Culture. Fontana.

$\mathrm{Wu}, \mathrm{Y}$. (2021). Can pop culture allay resentment? Japan's influence in China today. Media and Communication, 9(3), 112-122.

\section{About the Authors}

Ian Somerville is Head of the School of Media, Communication and Sociology at the University of Leicester, UK. His research has been published in a range of international communication, public relations, sociology, and politics journals and his most recent book is Public Relations, Society and the Generative Power of History (Routledge). He is currently a member of the editorial boards of Public Relations Review, Public Relations Inquiry and the Journal of Media and Communication.

Lee Edwards is Professor of Strategic Communications and Public Engagement in the Department of Media and Communications at the LSE. She teaches and researches strategic communications from a socio-cultural perspective and is particularly interested in the relationship between strategic communications (particularly public relations), inequalities, social justice, and democracy. She has published over 60 theoretical and empirical articles and book chapters on a range of topics including public relations as a cultural intermediary, diversity in public relations, and public relations and democracy. 